УДК 004.042

П. В. Чумаченко, Т. А. Ліхоузова, О. І. Лісовиченко МЕРЕЖІ ДОСТАВКИ КОНТЕНТУ

Анотація: Мережі доставки контенту (CDN) спрямовані на подолання обмежень, що властиві Інтернету. Метою $є$ зниження вартості послуг доставки контенту та підтримки мережі розповсюдження контенту. Для досягнення мети пропонується розподілена архітектура мережі (DCDN), яка використовує звичайних інтернет-користувачів для створення глобальної мережі CDN, що суттєво сприяє оптимізації та прискоренню веб-додатків без внесення значних початкових інвестицій. Успішність всієї системи базується на розробленому ефективному алгоритмі переадресації запитів, що виконується на локальних серверах.

Ключові слова: Мережі доставки контенту, CDN, маршрутизація запитів.

\title{
Опис проблеми
}

Постійне розширення World Wide Web спричинило експоненціальне зростання інтернет трафіку і контенту в мережі. Через зростанням кількості контенту в мережі окремі веб-сервери вже не в змозі задовольнити потреби кінцевих користувачів, тому задля накопичення та обслуговування такого обсягу контенту були впроваджені серверні ферми - кластери веб-серверів, що функціонують як єдине ціле. 3 часом серверним фермам також стає важко обробляти величезну кількість одночасних запитів до популярного контенту, що надається тим чи іншим веб-ресурсом. Крім цього серверні ферми частіше за все були географічно віддалені від кінцевих споживачів, що погано впливало на час відгуку запитів та сприяло виникненню небажаних затримок.

Вирішенням проблеми стає впровадження механізмів реплікації контенту між серверами, використовуючи глобальну мережу. Проте для окремого постачальника контенту встановлення власної мережі серверів є майже нездійсненною задачею, тому у 1998 році вперше було розглянуто концепцію мережі доставки контенту (Content Delivery Network, CDN) [1].

Основна її ідея полягає у підвищенні швидкості знаходження та отримання потрібного контенту за рахунок використання мережі географічно розподілених веб-серверів, що цей контент надають. В типовій архітектурі мережі кінцеві споживачі взаємодіють з CDN, відправляючи запити на отримання контенту, використовуючи ноутбуки, стаціонарні комп'ютери, смартфони тощо. Контент, який був

(c) П. В. Чумаченко, Т. А. Ліхоузова, О. І. Лісовиченко 
обраний на основі запитів користувачів, посилається до репліки. Тепер репліка зможе швидко обслужити інших клієнтів мережі, що будуть звертатися до цього контенту.

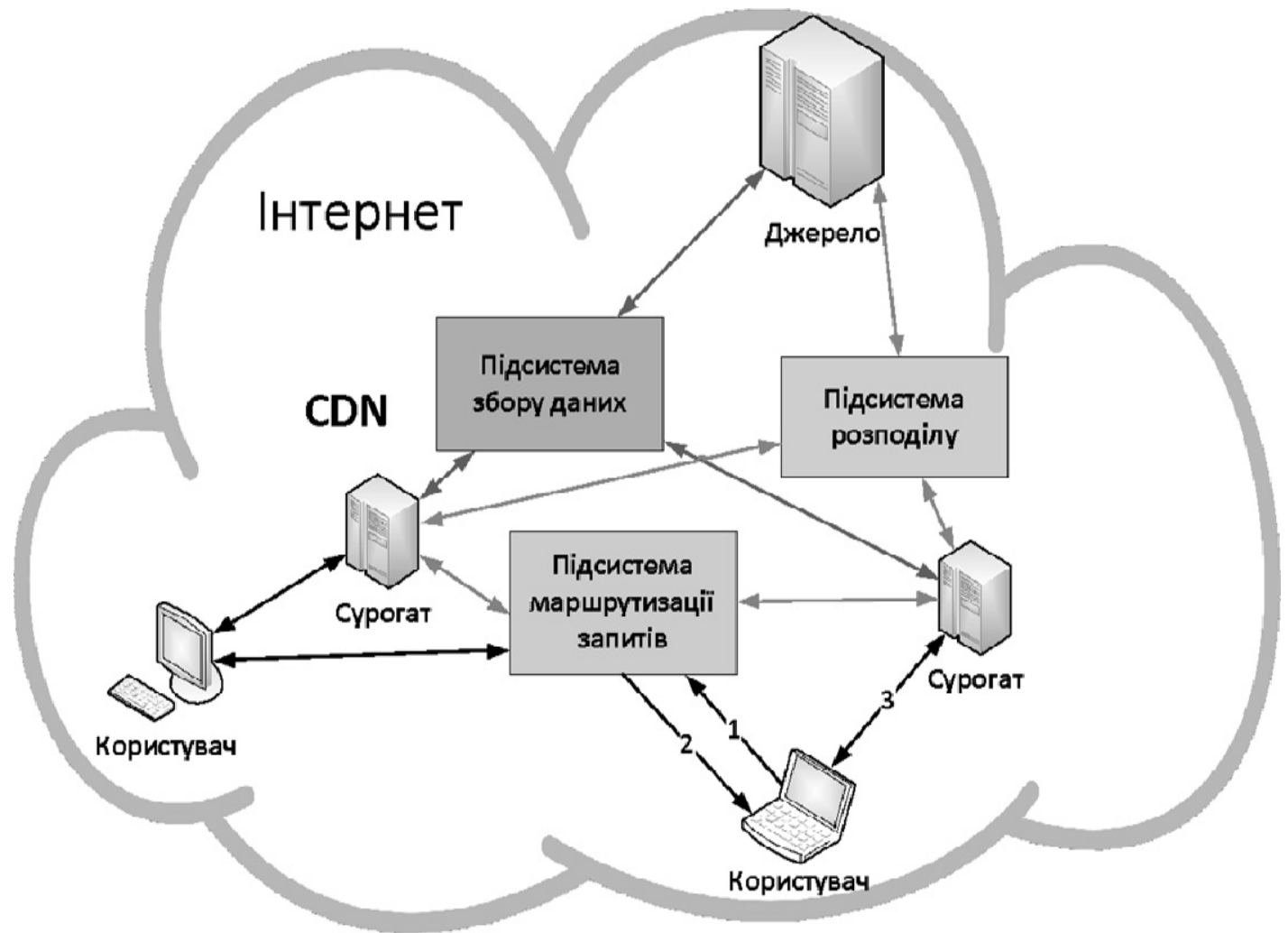

Рис. 1. Компоненти інфраструктури CDN

\section{Огляд існуючих архітектур CDN}

Технологія CDN подолала стрімкий шлях еволюції з моменту свого створення. Зараз по всьому світу існує ряд CDN систем [1, 2]. Разом вони називаються Conventional CDN. Ïх можна розділити на дві категорії:

- комерційні

- академічні

Власниками комерційних мереж є корпоративні компанії. Деякі 3 таких мереж налічують більш ніж 20000 серверів по всьому світу. Вони забезпечують хорошу масштабованість, тобто при збільшенні кількості клієнтів рівень надання послуг не погіршується. Доступність сервісу забезпечується також за рахунок існування резервних серверів. Іншою перевагою є високий рівень контролю за якістю послуг, що надаються. Проте найбільшим недоліком використання моделі CDN для розповсюдження контенту є висока вартість їі послуг. Це логічно, бо величезні фінанси, залучені для створення комерційної CDN, змушують провайдерів брати високу платню за надані по- 
слуги у клієнтів (постачальників контенту). Зазвичай вартість є настільки високою, що тільки компанії великого бізнесу можуть дозволити собі їі використання.

Академічні мережі використовують P2P архітектуру і не приносять прибутку. Модель однорангової мережі доставки контенту дозволяє провайдерам контенту використовувати власні хостингові платформи. Проте академічні CDN не надають мережу незалежних серверів по всьому світу. Це означає, що ефективність всієї системи залежить від надійності кожного з вузлів. Також варто зазначити, що немає жодних вбудованих ефективних заходів у архітектурі академічних CDN, які б вирішували цю проблему. Зазвичай провайдери контенту не мають змоги так ризикувати, тому і не вбачають академічні CDN як альтернативу комерційним.

\section{Постановка задачі}

Приведений вище аналіз [3] демонструє, що існує потреба у більш надійній і масштабованій архітектурі CDN, яка б не потребувала великих інфраструктурних інвестицій.

Таким чином, метою є зниження вартості послуг доставки контенту та підтримки мережі розповсюдження контенту. Для досягнення мети пропонується покращити архітектуру мережі, яка сприятиме оптимізації та прискоренню веб-додатків. Отже, виділяються наступні основні задачі, що вирішуватимуться:

- виконати дослідження, в результаті якого запропонувати архітектуру DCDN; визначити її переваги та недоліки;

- запропонувати алгоритм балансування навантаження для серверів DCDN;

- виконати порівняння продуктивності комерційної архітектури CDN та розробленої архітектури DCDN за допомогою симуляції на стенді.

Також варто зазначити, що на запропоновану реалізацію архітектури накладаються наступні обмеження: її впровадження та підтримка має бути дешевою або без значних початкових інвес тицій. 
Насправді, більшість існуючих архітектур мереж доставки контенту, що використовують Р2Р-підхід, ніколи не зможуть позмагатись 3 ефективністю і надійністю комерційних мереж. Як вже говорилося, мережа такої архітектури буде ефективна лише у випадку надійних та постійних учасників (пірів), чия продуктивність не перебуває під контролем запропонованої архітектури.

Архітектура DCDN, що пропонується у цій роботі, має за мету зниження цін на послуги доставки контенту у порівнянні з комерційними CDN, причому ефективність поширення контенту має лишатися принаймні на тому ж рівні. Запропонована архітектура може використовувати ресурси великої кількості звичайних веб-користувачів. Вона спирається на залучення веб-користувачів 3 порівняно високою пропускною здатністю інтернет-з'єднання, з яких формується мережа. Користувачі, що стають частиною мережі DCDN, називаються репліками. Вони замінюють звичайні сервери-репліки CDN, розміщуючись досить близько до кінцевих користувачів. Такий підхід має забезпечити підвищення ефективності розповсюдження контенту (тобто зменшення часу очікування), у зв'язку з тим, що контент поширюватиметься через місцеві мережі. Запропонована архітектура також сприяє зменшенню зовнішнього мережевого трафіку, оскільки контент доставлятиметься до кінцевих користувачів з локально розміщених реплік, що у свою чергу є вигідним для місцевих інтернетпровайдерів. Іншим об’єктом поданої архітектури є локальні сервери DCDN, які виконують ролі редиректора та балансувача навантаження, тобто призначені для перенаправлення клієнтських запитів до відповідних реплік $[4,5]$.

Успішність всієї системи DCDN базується на виборі ефективного алгоритму переадресації запитів. Для забезпечення масштабованості системи в межах певного регіону має бути присутня низка копій одного і того самого контенту, а їхня кількість має збільшуватиметься в геометричній прогресії разом із розширенням DCDN (рис. 2).

Локальний сервер DCDN має забезпечувати розподіл навантаження серед підпорядкованих йому реплік. Також він має слідкувати за доступністю або недоступністю тієї чи іншої репліки (рис. 3). 


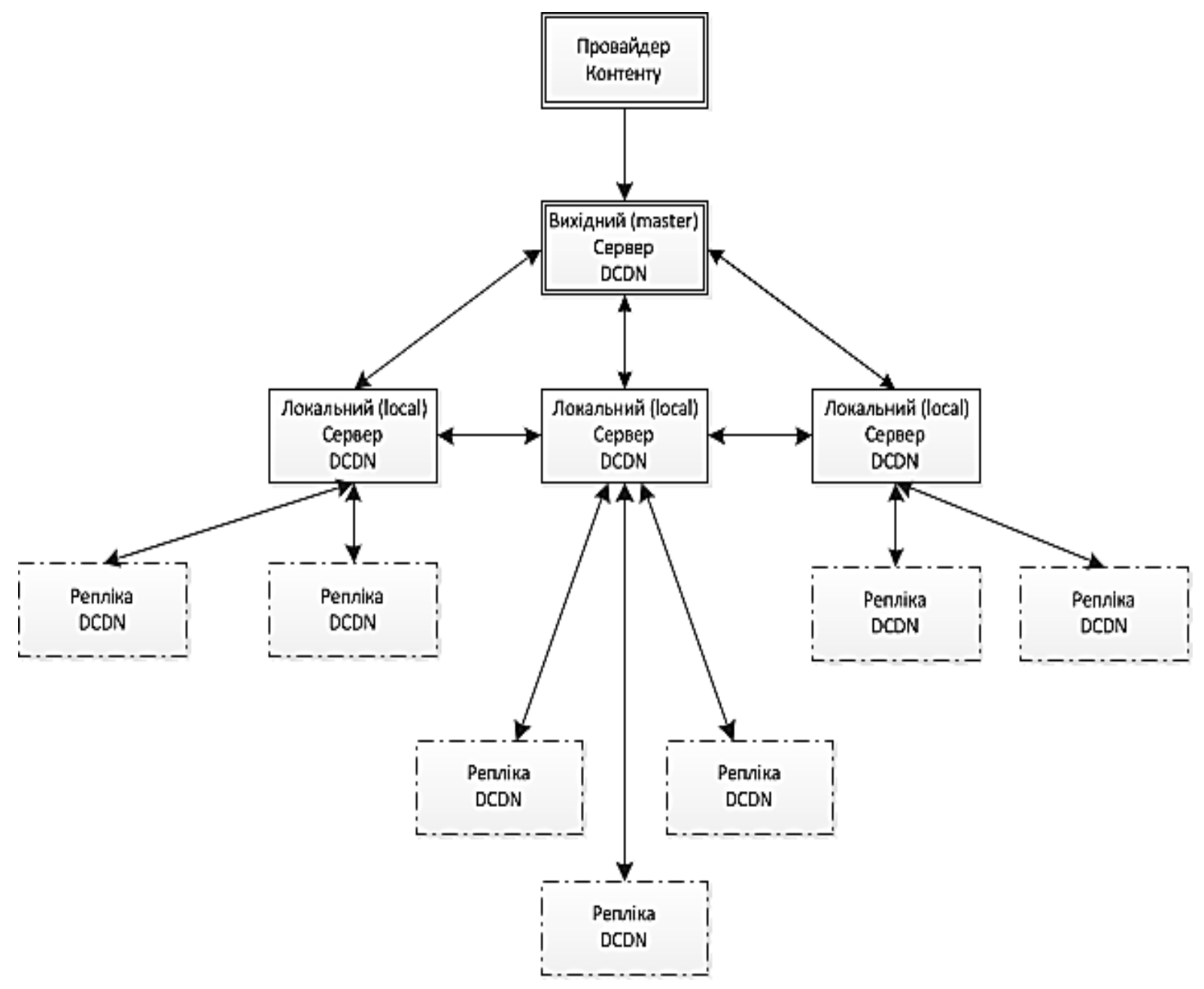

Рис. 2. Компоненти інфраструктури CDN

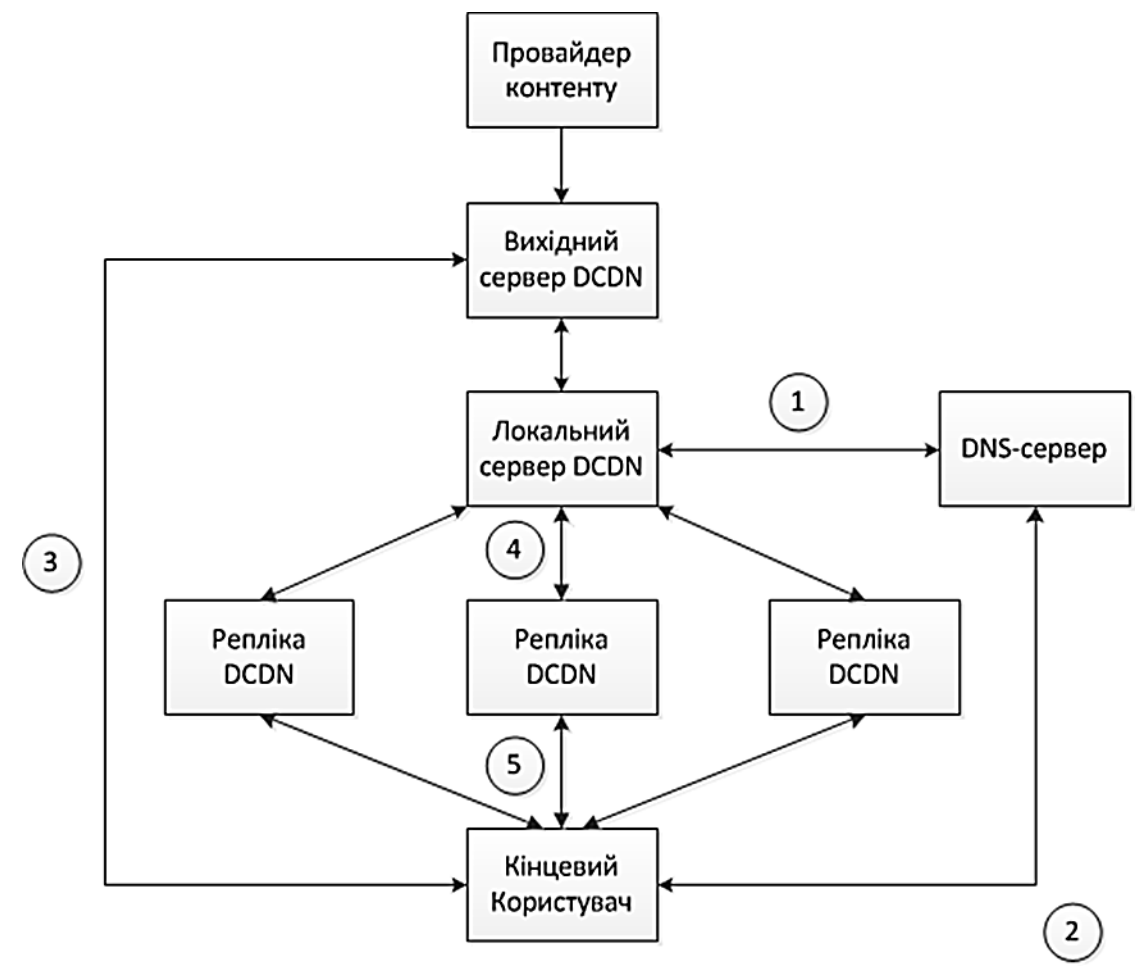

Рис. 3. Процес доставки контенту у DCDN 
Якщо запитуваний кінцевим користувачем контент відсутній у межах певного локального серверу, то такий сервер повинен мати змогу обрати інший локальний сервер, до якого можна звернутися для отримання бракуючого контенту, не викликаючи перенавантаження мережі (рис. 4).

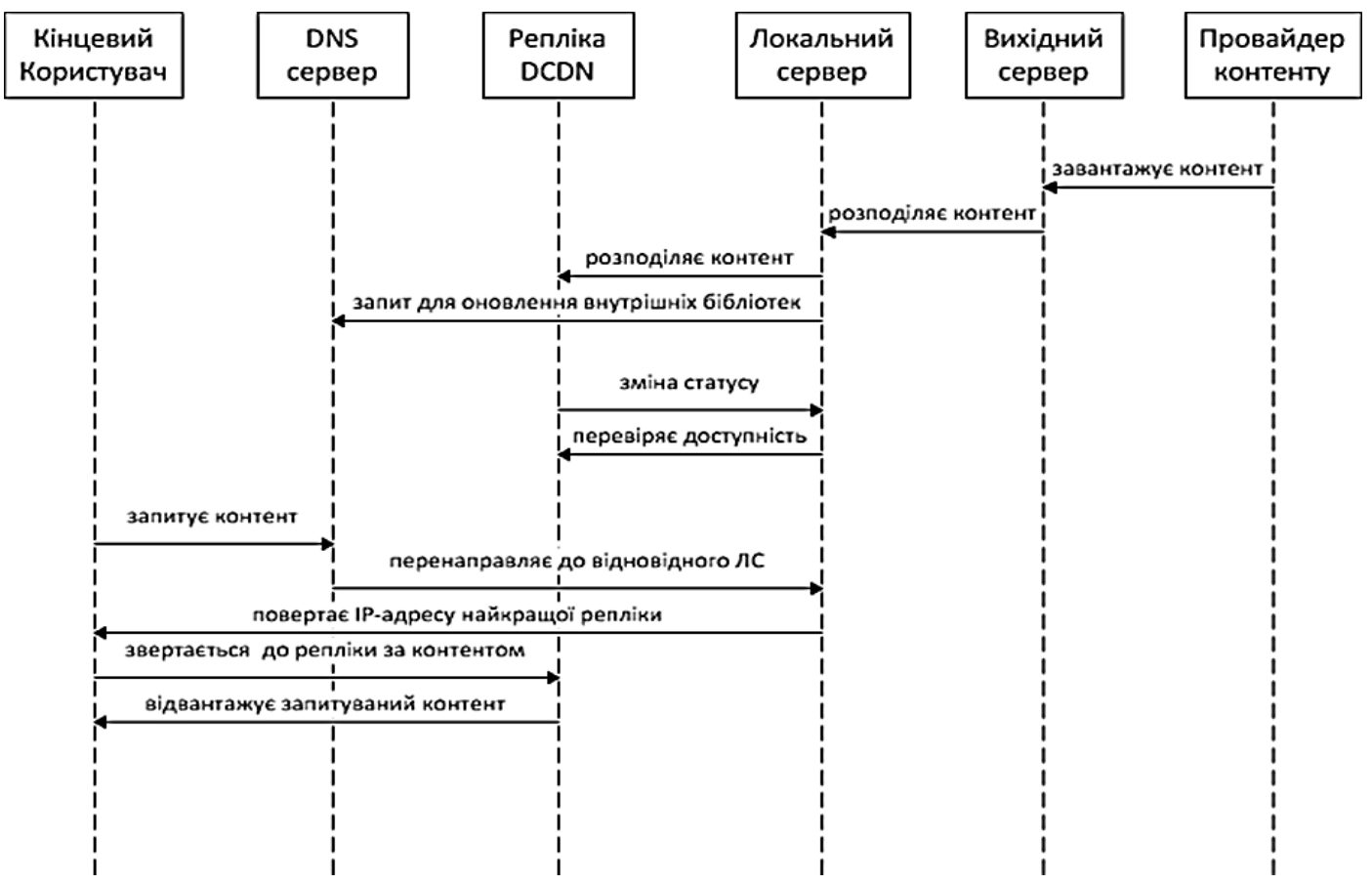

Рис. 4. Діаграма послідовності DCDN з урахуванням перевірки доступності реплік

\section{Алгоритм балансування навантаження}

Для розробки алгоритму балансування навантаження було проведено дослідження продуктивності реплік DCDN, базуючись на теорії масового обслуговування [6]. Під час аналізу використовувались моделі $\mathrm{M} / \mathrm{M} / \mathrm{c} / \mathrm{k}$ з експоненційним розподілом запитів ( $c$ - кількість залучених серверів або демонів серверів, а $k$ - загальний розмір буфера). У кожній з моделей оцінювалась середня затримка, що необхідна для обробки запитів, та інтенсивність відмови реплік DCDN.

Середній час очікування запиту в черзі $W$ є часом, який проходить від моменту потрапляння запиту у чергу до моменту, коли будьякий з серверів зможе обробити цей запит. Інтенсивність відмови $R \mathrm{\epsilon}$ кількістю запитів, які не будуть оброблені через перенавантаження за одиницю часу •

Порівняння результатів показало, що використання реплік M/M/c/с моделі масового обслуговування забезпечуватиме найвищу 
продуктивність системи. Також було отримано, що скорочення середньої затримки практично прямо пропорційне збільшенню швидкості завантаження даних $з$ реплік (upstream). На підставі отриманих даних був запропонований алгоритм балансування навантаження для серверів DCDN (рис. 5, 6).

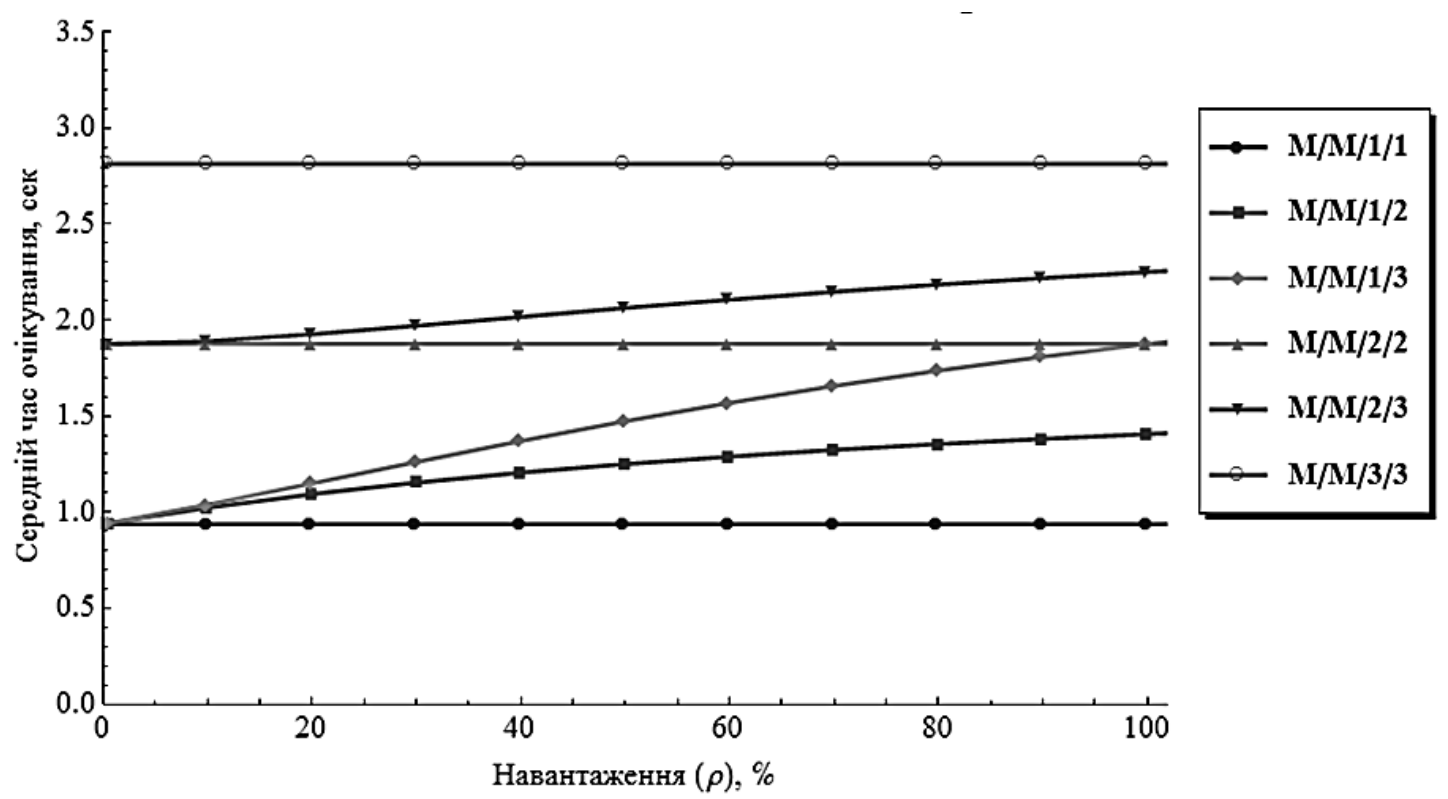

Рис. 5. Середній час очікування як функція навантаження репліки

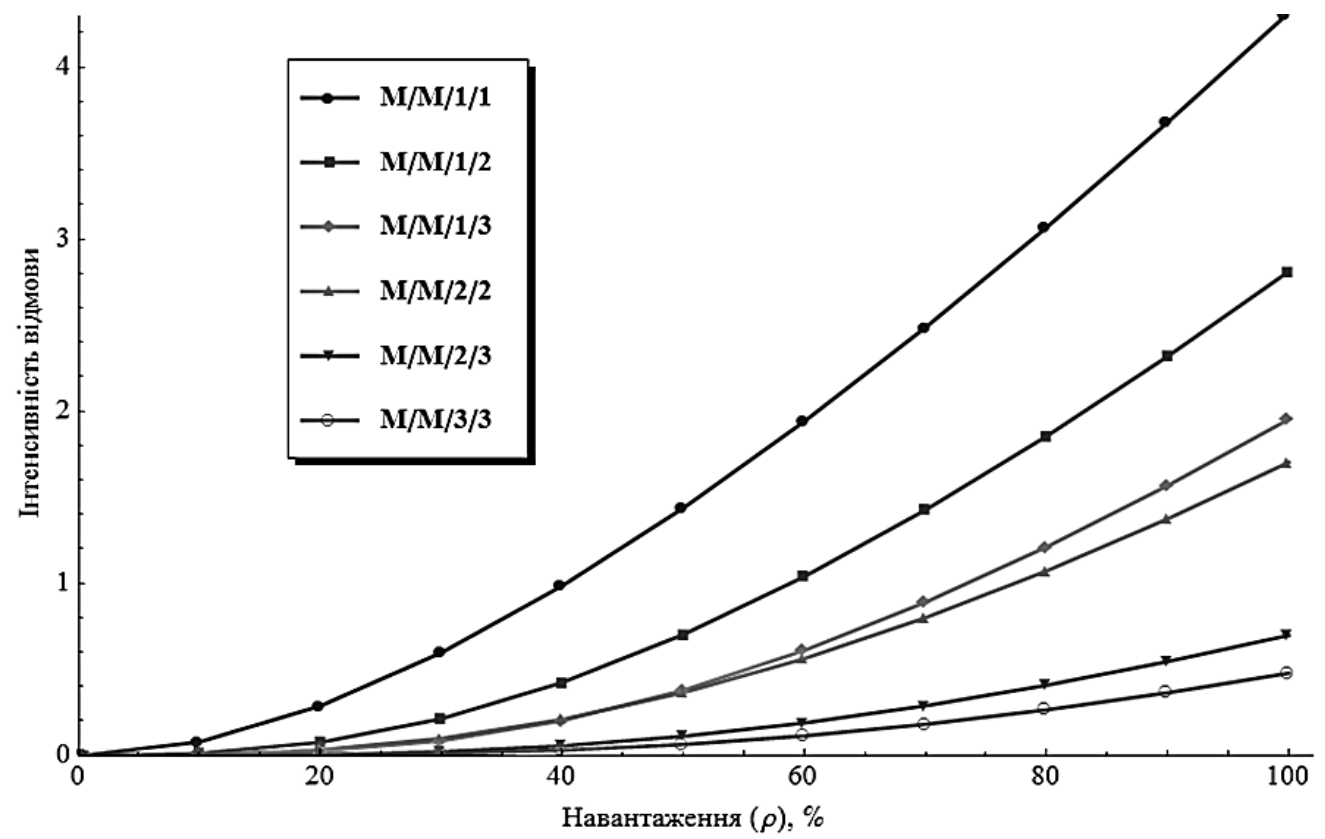

Рис. 6. Інтенсивність відмови як функція навантаження репліки

Очікується, що запропонований алгоритм (рис. 7) буде досить ефективно розподіляти робоче навантаження між репліками системи. Проте, це може бути підтверджено лише шляхом моделювання або 
проведення реальних випробувань. Параметри моделювання наведені в табл. 1, результати на рис. 8.

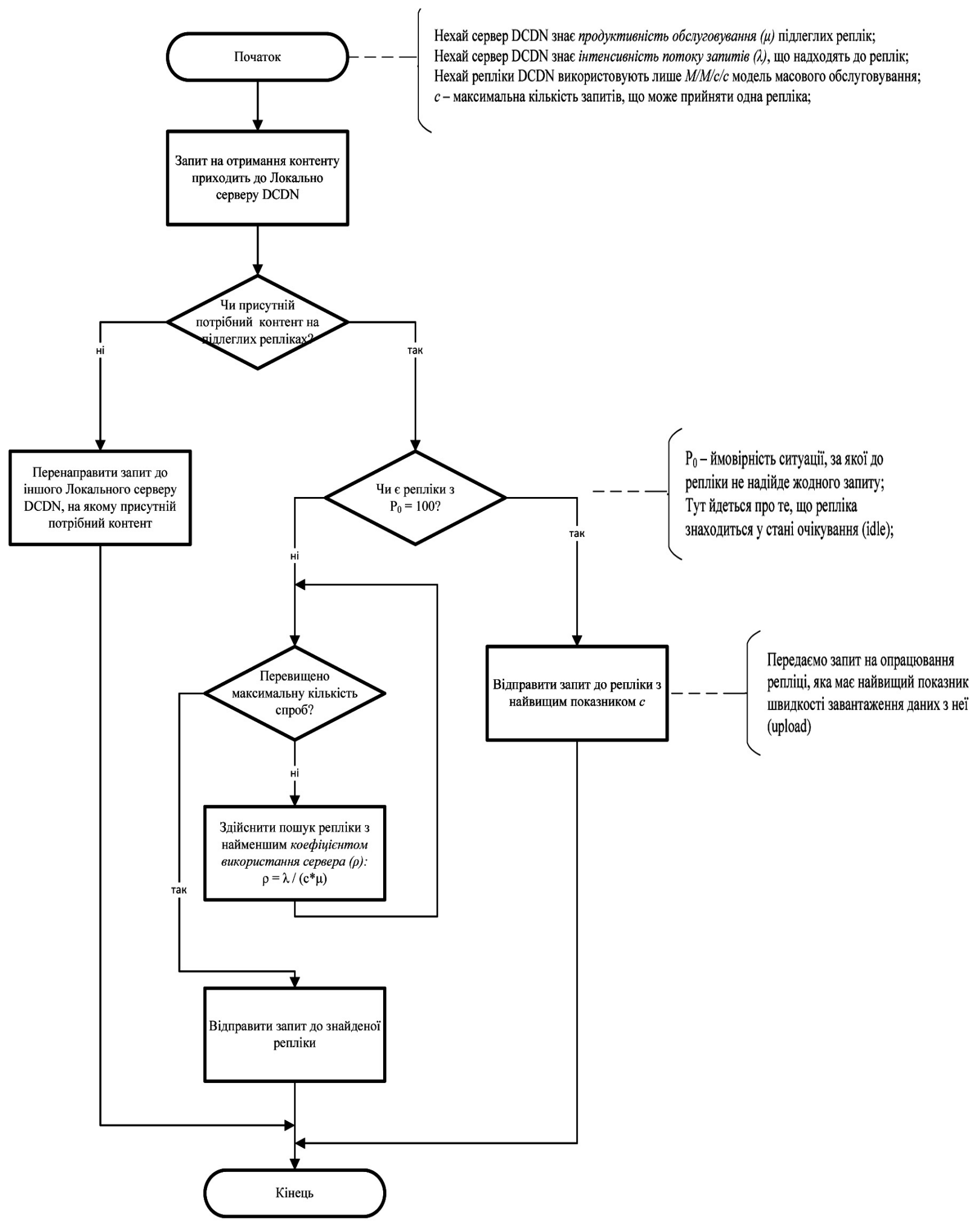

Рис. 7. Алгоритм балансування навантаження для сервера DCDN 
таблиия 1.

Параметри моделювання

\begin{tabular}{|l|c|c|c|c|}
\hline & $\begin{array}{c}\text { Комерційна } \\
\text { CDN }\end{array}$ & $\begin{array}{c}\text { DCDN } \\
\text { Сценарій \#1 }\end{array}$ & $\begin{array}{c}\text { DCDN } \\
\text { Сценарій \#2 }\end{array}$ & $\begin{array}{c}\text { DCDN } \\
\text { Сценарій \#3 }\end{array}$ \\
\hline $\begin{array}{l}\text { Кількість } \\
\text { кінцевих } \\
\text { користувачів }\end{array}$ & 150 & 150 & 75 & 30 \\
\hline $\begin{array}{l}\text { Кількість } \\
\text { реплік } \\
\text { (або серверів) }\end{array}$ & 3 & 6 & 6 & 6 \\
\hline $\begin{array}{l}\text { Пропускна } \\
\text { здатність } \\
\text { (Мбрь) }\end{array}$ & 100 & 10 & 10 & 10 \\
\hline $\begin{array}{l}\text { Алгоритм } \\
\text { балансування } \\
\text { навантаження }\end{array}$ & Round-robin & $\begin{array}{l}\text { Новий } \\
\text { алгоритм }\end{array}$ & $\begin{array}{c}\text { Новий } \\
\text { алгоритм }\end{array}$ & $\begin{array}{c}\text { Новий } \\
\text { алгоритм }\end{array}$ \\
\hline
\end{tabular}

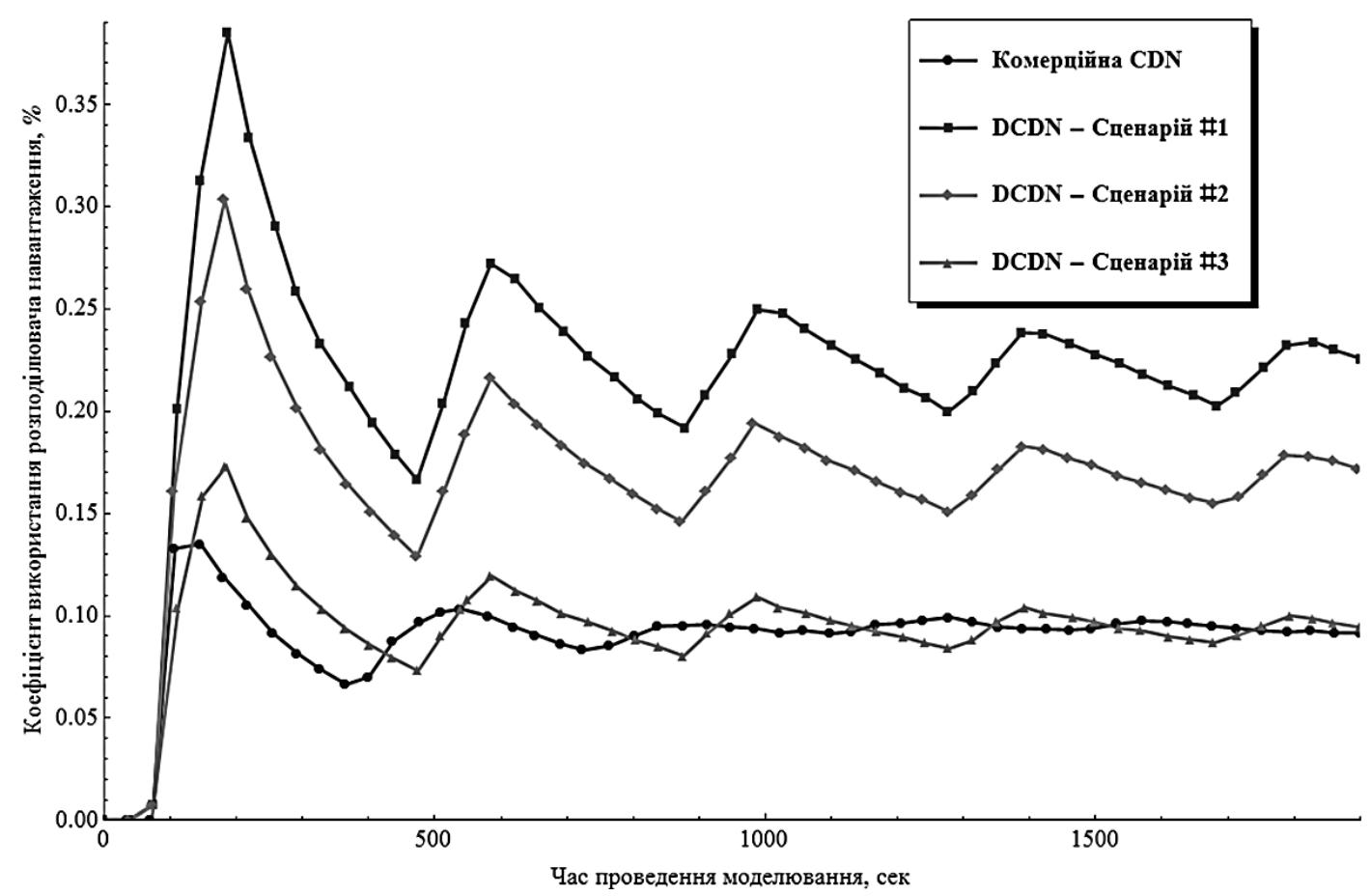

Рис. 8. Результати моделювання

Результати проведених моделювань свідчать про те, що архітектура DCDN може бути на стільки ж ефективною, як i архітектура комерційних клієнт-серверних $\mathrm{CDN}$, за умови дотримання відповідного балансу між інтенсивністю надходження запитів та кількістю реп- 
лік, що зможуть їх обробити. 3 іншого боку успіх DCDN в значній мірі залежить від росту популярності сервісу серед інтернет-користувачів. У цій архітектурі інтернет-користувачі мають вносити свою частку у підтримку DCDN та отримувати за це певні винагороди.

\section{Доставка контенту як двосторонній ринок}

Для визначення сильних та слабких сторін, можливостей та загроз для моделей розповсюдження контенту порівнюються три моделі розповсюдження контенту за допомогою методу SWOT аналізу (результати дослідження наведені в табл. 2). SWOT (сильні та слабкі сторони, можливості та загрози; Strengths, Weaknesses, Opportunities, Threats) [7, 8, 9] аналіз підсумовує ключові властивості компанії чи організації для визначення конкурентоздатності організації. Через те, що не існує жодної компанії чи організації для моделей розповсюдження контенту, аналіз проводиться з точки зору кожної моделі окремо.

Таблищя 2.

\section{Результати порівняння моделей розповсюдження контенту}

\begin{tabular}{|c|c|c|c|}
\hline & $\begin{array}{c}\text { Модель } \\
\text { «клієнт-сервер» }\end{array}$ & $\mathrm{CDN}$ & $\mathrm{CCN}$ \\
\hline $\begin{array}{l}\text { Витрати провайдера } \\
\text { контенту }\end{array}$ & Низькі & Високі & Низькі \\
\hline $\begin{array}{l}\text { Витрати інтернет- } \\
\text { провайдера }\end{array}$ & Помірні & Низькі & $\begin{array}{c}\text { Помірні / } \\
\text { Високі }\end{array}$ \\
\hline Масштабованість & Низька & Висока & Висока \\
\hline Затримка & $\begin{array}{l}\text { Висока / } \\
\text { Помірна }\end{array}$ & Помірна & $\begin{array}{l}\text { Низька / } \\
\text { Помірна }\end{array}$ \\
\hline $\begin{array}{l}\text { Контроль рівня якості } \\
\text { наданих послуг }\end{array}$ & Низький & Високий & Низький \\
\hline Доступність сервісу & Висока & Висока & $\begin{array}{c}\text { Висока / } \\
\text { Помірна / } \\
\text { Низька }\end{array}$ \\
\hline $\begin{array}{l}\text { Контроль провайдера } \\
\text { контенту за контентом }\end{array}$ & Високий & Помірний & Низький \\
\hline $\begin{array}{l}\text { Захист інтелектуальних } \\
\text { прав }\end{array}$ & Високий & Помірний & Низький \\
\hline
\end{tabular}

Отримані дані показують, що використання CDN для поширення контенту забезпечує чудову масштабованість, а також забезпечується доступність сервісу за рахунок існування резервних серверів. Іншою перевагою є високий рівень контролю за якістю послуг, що надаються. Проте найбільшим недоліком використання моделі CDN для розповсюдження контенту $є$ висока вартість ї послуг. Архітектура 
DCDN, що пропонується, має за мету зниження цін на послуги доставки контенту у порівнянні з комерційними CDN, причому ефективність поширення контенту має лишитися принаймні на тому ж рівні. Це б дозволило середнім та малим компаніям користуватися послугами розповсюдження контенту.

\section{Висновки}

Запропоновано розподілену архітектуру мережі доставки контенту (DCDN), яка використовує ресурси великої кількості звичайних веб-користувачів, що замінюють звичайні сервери-репліки CDN, розміщуючись досить близько до кінцевих користувачів. Такий підхід забезпечує підвищення ефективності розповсюдження контенту (тобто зменшення часу очікування), за рахунок поширення контенту через місцеві мережі. Запропонована архітектура також сприяє зменшенню зовнішнього мережевого трафіку, оскільки контент доставлятиметься до кінцевих користувачів з локально розміщених реплік, що у свою чергу є вигідним для місцевих інтернет-провайдерів.

Успішність всієї системи DCDN базується на ефективному алгоритмі переадресації запитів, що виконується на локальних серверах DCDN. Для розробки алгоритму балансування навантаження було проведено дослідження продуктивності реплік DCDN. Аналіз результатів показав, що використання реплік $\mathrm{M} / \mathrm{M} / \mathrm{c} / \mathrm{c}$ моделі масового обслуговування забезпечуватиме найвищу продуктивність системи, а також скорочення середньої затримки практично прямо пропорційне збільшенню швидкості завантаження даних 3 реплік. На підставі отриманих даних був запропонований алгоритм балансування навантаження для серверів DCDN.

Проведено порівняльний аналіз трьох моделей розповсюдження контенту: клієнт-серверної, CDN та CCN. Отримані дані показали, що використання CDN для поширення контенту забезпечує чудову масштабованість, крім того забезпечується доступність сервісу за рахунок існування резервних серверів. Іншою перевагою є високий рівень контролю за якістю послуг, що надаються. Архітектура DCDN, що пропонується, дає можливість зниження цін на послуги доставки контенту у порівнянні з комерційними $\mathrm{CDN}$, причому ефективність поширення контенту може лишатися на тому ж рівні. Apхітектура DCDN пропонує винагороди кожній зі своїх реплік, величина яких залежить від обчислювальної потужності, ширини інтернет-підключення, а також від часу, 
який репліка буде доступною (он-лайн). Винагороди мають стимулювати репліки надавати якомога кращі послуги, а отже і підтримувати існування DCDN в цілому, що у свою чергу дозволить забезпечувати провайдерів контенту та кінцевих користувачів якісним сервісом.

\section{Список використаних джерел}

1. D. C. Verma Content Distribution Networks: An engineering approach / Wiley Inter-Science, 2002.

2. R. Buyya Content Delivery Networks / Springer-Verlag Berlin Heidelberg, 2008.

3. T. А. Ліхоузова Огляд концепції мереж доставки контенту // Т. А. Ліхоузова, П. В. Чумаченко / Міжвідомчий науковотехнічний збірник «Адаптивні системи автоматичного управління» № 1(28), 2016 - c. 67-75.

4. Б. Годфрі. Балансування навантаження у динамічних Р2Р системaх / Б. Годфрі, С. Сурана, Р. Карп, Й. Стойка / Двадцять третя щорічна Спільна Конференція IEEE комп'ютерних та комунікаційних товариств, 2253-2262, березень 2004.

5. K.S.Candan Enabling dynamic content caching for database-driven web sites / K. S. Candan, W.-S.Li, Q. Luo, W.-P. Hsiung, D. Agrawal, In Proc. of ACM/SIGMOD Conference 2001, Santa Barbare, California, USA, May 2001.

6. T. A. Ліхоузова Мережі доставки контенту // Т. А. Ліхоузова, П. В. Чумаченко / XI Международная научно-практическая конференция «Научная индустрия европейского континента - 2015» 22-30.11.2015, Прага, Чехия - с. 92-94.

7. П. Фаратін. Взаємозв язок диференціацій: Перспективи двосторонніх ринків / П. Фаратін, Т. Вілкенін / Конференція HotNets-V, Ірвін, Каліфорнія, США, листопад 2006.

8. П. Джонсон Дослідження корпоративної стратегії / П. Джонсон, M. Шулес, Г. Вітінгтон / Financial Times Prentice Hall, 2005г. 57-93 c.

9. T. А. Ліхоузова Оцінка якості передачі мови в IP-телефонії / Т. А. Ліхоузова, К. М. Носенко // Міжвідомчий науковотехнічний збірник «Адаптивні системи автоматичного управління» № 2(27), 2015 - с.74-79. 